\title{
CONCEPTUAL COST ESTIMATION FRAMEWORK FOR MODULAR PROJECTS: A CASE STUDY ON PETROCHEMICAL PLANT CONSTRUCTION
}

\author{
Younguk $\mathrm{CHOI}^{1}$, Chan Young PARK ${ }^{2}$, Changjun $\mathrm{LEE}^{1}$, Sungmin $\mathrm{YUN}^{3 *}$, Seung Heon $\mathrm{HAN}^{1 *}$ \\ ${ }^{1}$ Department of Civil and Environmental Engineering, Yonsei University, Seoul, Republic of Korea \\ ${ }^{2}$ Intelligent Construction Automation Center, Kyungpook National University, Daegu, Republic of Korea \\ ${ }^{3}$ Department of Civil Engineering, Yeungnam University, Gyeongsan, Republic of Korea
}

Received 25 May 2021; accepted 17 November 2021

\begin{abstract}
Modularization, which allows for pre-assembly away from a construction site, has been known to be more cost-effective than stick-built; however, contractors have difficulty ascertaining the benefits and adopting it. Calculating the benefits and costs of adopting modularization precedes decision making. However, modular cost estimation is challenging since relevant information in the early stages of a project and historical data about industrial modularization both have limited availability. To solve this problem, this study developed a conceptual cost estimation framework for industrial modular projects by converting stick-built project information. The framework is composed of eight steps based on two approaches. This study conducted a case study to demonstrate the applicability of the framework, which compared the project cost of modularization scenarios 1 and 2 with that of the stick-built version of the ongoing project. In addition, the estimated modular cost was compared with the engineers' estimation to verify the accuracy of the framework. The contributions of this study are in identifying and quantifying the factors influencing the differences in cost between the modularization and stick-built versions, and developing the conceptual cost estimation framework for an industrial modular project. This framework is expected to support deciding on adopting modularization, budgeting, and project viability.
\end{abstract}

Keywords: modularization, industrial modular projects, conceptual cost estimation, quantity-based estimation, MonteCarlo simulation.

\section{Introduction}

Modularization allows for pre-assembly away from a construction site and includes a process of transporting and installing complete systems to the site (Haas et al., 2000). Modularization receives the widespread support from contractors since it can reduce project duration, accident rates, and project risk, and improve labor productivity, the work environment, and management capabilities (Choi \& Song, 2014; Choi et al., 2019b; O'Connor et al., 2014). Over the course of decades, some of advanced contractors have tried to apply modularization to their projects in order to improve profits. However, despite this growing attention to modularization, most contractors have difficulty ascertaining the benefits and adopting it for their projects because of a lack of experience and knowledge (Wuni et al., 2020). Many contractors have attempted to do modular project execution using a trial-and-error approach.
Industry practitioners have to make several initial decisions in order to have a successful project. Cost estimation is crucial to making major decisions such as budget al.ocation, alternative selection and the modularization decision in the early stages (Kinney \& Soubiran, 2004; Oberlender \& Trost, 2001). Cost estimation in the early stages is difficult due to the low level of available information and the typically limited project definition (Choi et al., 2014). The project scope easily can change from the initial plan because detailed information is not yet determined (Choi, 2014). Moreover, due to insufficient experience with modular projects, historical data is scant to accurately estimate the cost of the modularization decision (Mao et al., 2016).

In this context, several studies have investigated the cost of modular construction compared with stick-built construction (Construction Industry Institute [CII], 2002;

*Corresponding author. E-mail: smyun@yu.ac.kr

${ }^{\#}$ Corresponding author. E-mail: shh6018@yonsei.ac.kr 
O'Connor et al., 2013; Pan et al., 2012). Various studies have investigated the way to apply the modularization method and help practitioners increase the efficiency of modular construction (Choi \& Song, 2014). To date, most of those studies have assessed the problems at the strategic level, but an economic approach for estimating the cost of modularization is missing. Decisions about adopting modularization are complex problems (Wuni et al., 2019). Both practitioners and researchers need to understand the cost variances underlying the construction method decisions (i.e., the differences between modular and stick-built construction) prior to establishing the strategies for a project. Thus, this study aims to develop a conceptual cost estimation framework to support decision-making toward adopting the modularization approach.

To achieve this aim, this study sets out a conceptual cost estimation framework that converts the stick-built cost (which has relatively plentiful historical data to modularization cost (which does not have such data). Two main research activities were used to develop the cost estimation framework: (1) the factors affecting the differences in cost between stick-built and modularization were identified by literature review, and (2) the magnitude of those differences was quantified into probability and impact factors by a survey and interview of experts' knowledge and experience. The cost estimation framework was established based on these two approaches: (1) quantitybased estimation (QBE) and (2) Monte-Carlo simulation (MCS). A detailed description and the methodology of the framework are discussed in the following sections.

This study proceeded via four research steps: (1) reviewing the literature to understand the state of the art of research and set up the research problems; (2) capturing experts' knowledge and experience and developing the cost estimation framework based on two approaches; (3) conducting a case study to verify the functionality of the developed framework; and (4) discussing the results and findings of the case study.

\section{Research background}

\subsection{Overview of industrial modular project research}

Several studies have been conducted to improve the performance of modularization from the perspective of construction management. Studies on the construction management approach can be divided into two branches: (1) applicability of modularization and (2) optimization of the modular process.

In the first area, determining a proper construction method for a project at an early stage is critical to improving project performance (Naqvi et al., 2014). In order to the need to meet the changing market environment, as well as improving performance, the adoption of modularization in industrial projects is expected to grow (CII, 2002). However, many researchers have emphasized that unconditional use of modularization can have negative impacts. It is important to understand modularization in the context of the characteristics of individual projects and environmental conditions (Choi et al., 2019a; CII, 2002). Therefore, previous studies have focused on deriving critical factors affecting the applicability of modularization (Choi \& Song, 2014; O'Connor et al., 2013, 2014). These studies classified the project characteristics relevant to adopting modularization and developed the decisionmaking criteria to examine the feasibility of such adoption. Although conceptual cost estimation and changes in total project cost have greater impact on decision-making, previous studies were limited in that they focused only on the constructability and applicability of modularization.

In the second area, many researchers have studied optimizing the benefits of modularization such that they are maximized (Chowdhury, 2016; Hsu et al., 2018; O'Connor et al., 2015; Taghaddos et al., 2010). Modularization can benefit by having parallel work done simultaneously at the construction site and in fabrication shops. Also, work in fabrication shops can reduce risks existing at the construction site and improve productivity (Jameson, 2007). To maximize these types of benefit, several studies have sought to optimize resource allocation and the supply chain from a logistics perspective (Hsu et al., 2018; Taghaddos et al., 2010). Other studies have focused on the interface between the fabrication shops and the construction site (Chowdhury, 2016). These studies are important because modularization includes additional phases (i.e., fabrication, transportation, and installation) compared to the stick-built process. However, there is a lack of understanding of cost variation and changes in the total project cost due to these additional phases.

The existing studies have widely discussed the applicability and optimization associated with the use of a modular method in industrial projects compared with traditional construction method. Despite advantage of modularization, the industry has not yet been able to fully apply modularization (Abdul Nabi \& El-adaway, 2020; O'Connor et al., 2014). Decisions about adopting modularization are complex problems (Wuni et al., 2019). Both practitioners and researchers need to understand the cost variances according to construction method decisions (i.e., the differences between modular and stick-built construction) prior to establishing the strategies for a project. However, existing studies lacked consideration of cost aspects during modularization decision.

\subsection{Review of cost estimation in construction industry research}

For conceptual cost estimation at an early stage of a project, many studies have developed a cost estimation model by using various techniques. Table 1 summarizes previous studies on construction industry. These studies emphasized that the cost estimation model and framework should be simple, quick to use and provide trustworthy results, even if an accurate prediction is difficult due to a lack of available information (Oberlender \& Trost, 2001). 
Table 1. Overview of project estimation methods

\begin{tabular}{|l|l|l|}
\hline \multicolumn{1}{|c|}{$\begin{array}{c}\text { Estimation } \\
\text { method }\end{array}$} & \multicolumn{1}{|c|}{ Description and features } & \multicolumn{1}{c|}{ References } \\
\hline $\begin{array}{l}\text { Artificial } \\
\text { intelligence }\end{array}$ & $\begin{array}{l}\text { Plays an innovative role in the cost estimation by performing thinking and } \\
\text { learning from considerable input data, e.g., artificial neural networks }\end{array}$ & $\begin{array}{l}\text { Dursun and Stoy (2016); } \\
\text { Hashemi et al. (2019); } \\
\text { Petroutsatou et al. (2012) }\end{array}$ \\
\hline $\begin{array}{l}\text { Parametric } \\
\text { estimation }\end{array}$ & $\begin{array}{l}\text { A statistical technique that estimates and optimizes the cost of a system as a } \\
\text { parameter that constitutes the system and applies the factors to the cost drivers as } \\
\text { empirical coefficients with the other characteristics }\end{array}$ & $\begin{array}{l}\text { Chou et al. (2006); Kwak and } \\
\text { Watson (2005); Yu (2006) }\end{array}$ \\
\hline $\begin{array}{l}\text { Regression } \\
\text { estimation }\end{array}$ & $\begin{array}{l}\text { A statistical analysis method for modeling the relations among several variables } \\
\text { as a functional formula and indicating a single dependent variable as a linear } \\
\text { function with one or more independent variables }\end{array}$ & $\begin{array}{l}\text { Kim et al. (2004); Sonmez } \\
\text { et al. (2007) }\end{array}$ \\
\hline $\begin{array}{l}\text { Case-based } \\
\text { reasoning }\end{array}$ & $\begin{array}{l}\text { An inference method that can solve new problems by reusing relevant } \\
\text { information and knowledge based on previous similar cases }\end{array}$ & $\begin{array}{l}\text { Choi et al. (2014); Koo et al. } \\
\text { (2011) }\end{array}$ \\
\hline $\begin{array}{l}\text { Quantity-based } \\
\text { Estimation }\end{array}$ & $\begin{array}{l}\text { The estimate using limited information by deriving representative work for each } \\
\text { project and calculating the quantity and cost for each work item separately }\end{array}$ & $\begin{array}{l}\text { Kim et al. (2009); Smith et al. } \\
\text { (2018) }\end{array}$ \\
\hline $\begin{array}{l}\text { Simulation } \\
\text { estimation }\end{array}$ & $\begin{array}{l}\text { A technique to predict the actual results by modeling a phenomenon or an event, } \\
\text { using a systematic tool }\end{array}$ & $\begin{array}{l}\text { Chou et al. (2009); Kang and } \\
\text { Kim (2018); Zhu et al. (2016) }\end{array}$ \\
\hline $\begin{array}{l}\text { Activity-based } \\
\text { estimation }\end{array}$ & $\begin{array}{l}\text { Focuses on calculating the cost of each unit of the activities by dividing the } \\
\text { performing business into discrete pieces of work }\end{array}$ & $\begin{array}{l}\text { Kim and Cho (2013); Staub- } \\
\text { French et al. (2003) }\end{array}$ \\
\hline $\begin{array}{l}\text { BIM-integrated } \\
\text { estimation }\end{array}$ & $\begin{array}{l}\text { An estimation which enables to consider various attribute of design aspect and to } \\
\text { change the estimates automatically according to design }\end{array}$ & $\begin{array}{l}\text { Cheung et al. (2012); Fazeli } \\
\text { et al. (2020) }\end{array}$ \\
\hline
\end{tabular}

Since related information is insufficient in the early stages of projects (Chou et al., 2009), efforts have been made to increase accuracy by using available construction cost data (Smith et al., 2018).

Although these studies contribute to the body of knowledge of cost estimation for various structures, they rarely consider industrial modular projects in conceptual planning (Choi et al., 2019a). Cost estimation for the industrial modular project is challenging due to the additional processes involved. Capturing the cost variation associated with the use of modularization requires the consideration of factors influencing the cost (Bertram et al., 2019). In this sense, the characteristics of modular projects should be considered adequately to conceptually estimate the project cost in early stage. This research aims to establish framework associated with additional modularization process applying quantity-based estimation and simulation methods among various cost estimation methods. Since these methods do not require large amount of data, framework developed can overcome the lack of industrial modular projects information and seeks to identify a means to make decisions in early stage of the project.

\subsection{Research objectives}

Most previous studies which identified the characteristics of modular construction projects sought to determine the advantages and disadvantages of modularization (Abdul Nabi \& EI-adaway, 2021; O'Connor et al., 2014). Various factors and decision-making criteria were provided for successful projects. Despite their contributions, previous studies have several limitations for practical use. First, little effort was made to quantitatively grasp the comprehensive impact of modularization. It is important to quantify the impact of modularization in an early stage of each project in order to capture relevant cost reductions. However, previous studies have not presented appropriate approaches for the industrial modular sector. As an industrial modular project is carried out, the total project cost changes depending on the additional processes needed for modularization. Second, previous studies have not been able to fill the knowledge gap between academia and practice, as mentioned above. Practitioners tend to wonder how much profit will be made when adopting the construction method for their projects. If the approximate cost of a modular construction can be estimated, contractors can be helped toward selecting that construction method compared with the stick-built approach. Therefore, this study aimed to develop a conceptual cost estimation framework for industrial modular projects that could be applied by inexperienced contractors at an early stage of projects.

\section{Research method}

\subsection{Concepts of cost estimation framework}

The authors designed the structure of the framework based on practitioners' practical or academic knowledge and relevant experience. There are three key elements that critically influence cost for industrial modular projects. The author interviewed industry practitioners about how to effectively estimate the cost for such projects.

Previous studies attempted to use many similar completed cases to predict total project cost. However, industry practitioners claimed that, when estimating industrial modular projects, it is difficult to find several modular project cases to use for a basis. Thus, it was recommended 
that estimation would be conducted based on the quantity and cost using the stick-built method, for which there is sufficient information in the early stages. The concept of our cost estimation method is set to calculate project cost changes based on the quantity changes of work items used when modularization is adopted.

Another key issue regarding estimation for industrial modular projects from some practitioners was estimating the cost of additional phases (i.e., fabrication, transportation, and installation costs), which is the most important factor in such a project. The work items are converted to modules and moved from fabrication shops to the construction site. To overcome the limitations of a lack of industrial modular project case data, some practitioners suggested the use of the construction cost database, which provides reliable information updated annually (such as all-in-rate, location factor, and productivity factors). In construction research, several attempts have been made to estimate total project cost in an early stage (Smith et al., 2018), which helps reduce the chance of discrepancies due to lack of information and a limited project definition.

Furthermore, there was a recommendation for identifying the modularization effects in order to revise the initial estimates. Some industry experts recommended quantifying and reflecting industry-specific influencing factors, which would show negative and positive effects on modular projects compared to stick-built projects. After an extensive literature review, this study adopted the probability and impact of factors based on previous industrial modular projects. To calculate the cost impact, the MonteCarlo simulation method was used based on the assumed distribution of each factor.

\section{Approach 1: Quantity-based estimation}

Quantity based estimation (QBE) has several advantages as a tool for calculating the cost using the type of work item and the approximate cost per quantity of work. First, QBE allows semi-detailed cost estimates according to the project cost structure, so that an effective cost estimation can be conducted (Chou et al., 2006; Soutos \& Lowe, 2005). Second, QBE can be applied in a limited time for decision-making or alternative selection (Kim \& Cho, 2013). Once the unit quantity of the work items is determined, the cost estimation can be approximated using the construction cost database, which provides potential costs associated with each work item (Bell \& Kaminsky, 1987). Such a database comprises the national averages and construction information updated annually; such information provides costs of labor, materials, general overhead, and profit.

In this study, QBE is used to identify the quantity changes in work items and to calculate the required weight of the modules. Then, this study calculated not only the fabrication cost but also the related transportation and installation costs, by using the construction cost database (Compass International Inc., 2016a, 2016b; Smith et al., 2018).

\section{Approach 2: Monte-Carlo simulation}

Monte-Carlo simulation (MCS) is a probabilistic statistical method that overcomes the limitations of deterministic methods (Touran \& Wiser, 1992). MCS is suitable for solving problems in the construction industry with limited cases because relatively few data points can be defined as probability distributions and run through several simulations (Zhu et al., 2016). Since a range of values is derived from MCS, rather than a single value, decision-makers can choose the appropriate value corresponding to the desired probability distribution for their project (Touran \& Wiser, 1992). Since it is usually helpful to analyze the uncertainty of cost changes, many contractors have attempted to apply MCS to evaluate project cost variation (Zhu et al., 2016).

To perform MCS, it is necessary to assume that uncertain variables take the form of probability distributions. If considerable data are available, a statistical analysis can be used for a normal distribution. However, if there are few data, the uniform distribution or triangular distribution should be used (Touran, 1993). The triangular distribution is suitable for a construction project for which it is difficult to analyze and extract reliable cost data (Back et al., 2000). In addition, the Bernoulli distribution is a discrete probability distribution of a random variable that shows only two possible outcomes (Uspensky, 1937) and is used to indicate whether an event occurs. Therefore, this study uses the triangular distribution to quantify the impact of the factors and the Bernoulli distribution to set their probability of occurrence.

\subsection{Framework formulation}

The framework comprises nine steps according to the availability of the contractors' module information. The QBE approach (Approach 1) is addressed in Steps 1 to 6, which inform the estimating process using the unit cost of work items. The MCS approach (Approach 2) is addressed in Steps 7 and 8 to quantify the impact of cost factors and present the total project cost as a probabilistic range. Figure 1 shows the procedures of the developed framework to support the reader in understanding the logical links between each sequential step. This framework can be used once the conceptual design for the stick-built approach to the project has been completed, so that the quantity and cost of the work items can be determined. To determine which of the national averages in construction cost data should be used, the expected location of the construction site and fabrication shops must be decided. A detailed demonstration of the framework is described in the next section through a case study.

\section{Step 1: Customizing work items}

The purpose of Step 1 is to define the cost structure of the work items that can be accessed in the early stages. Industrial projects have a complex structure wherein various elements, such as civil, architectural, chemical, mechanical, and electrical, are combined. The cost structure of the work items cannot be generalized with one clas- 
sification system due to the characteristics of the projects and contractors and the requirements of the owner and organizational environment. Thus, the user must define the cost structure of the work items that can represent the particular projects.

Generally, 20\% of work items with high volume normally take more than $80 \%$ of the total project cost (Kim et al., 2009). Therefore, it is possible to estimate the total

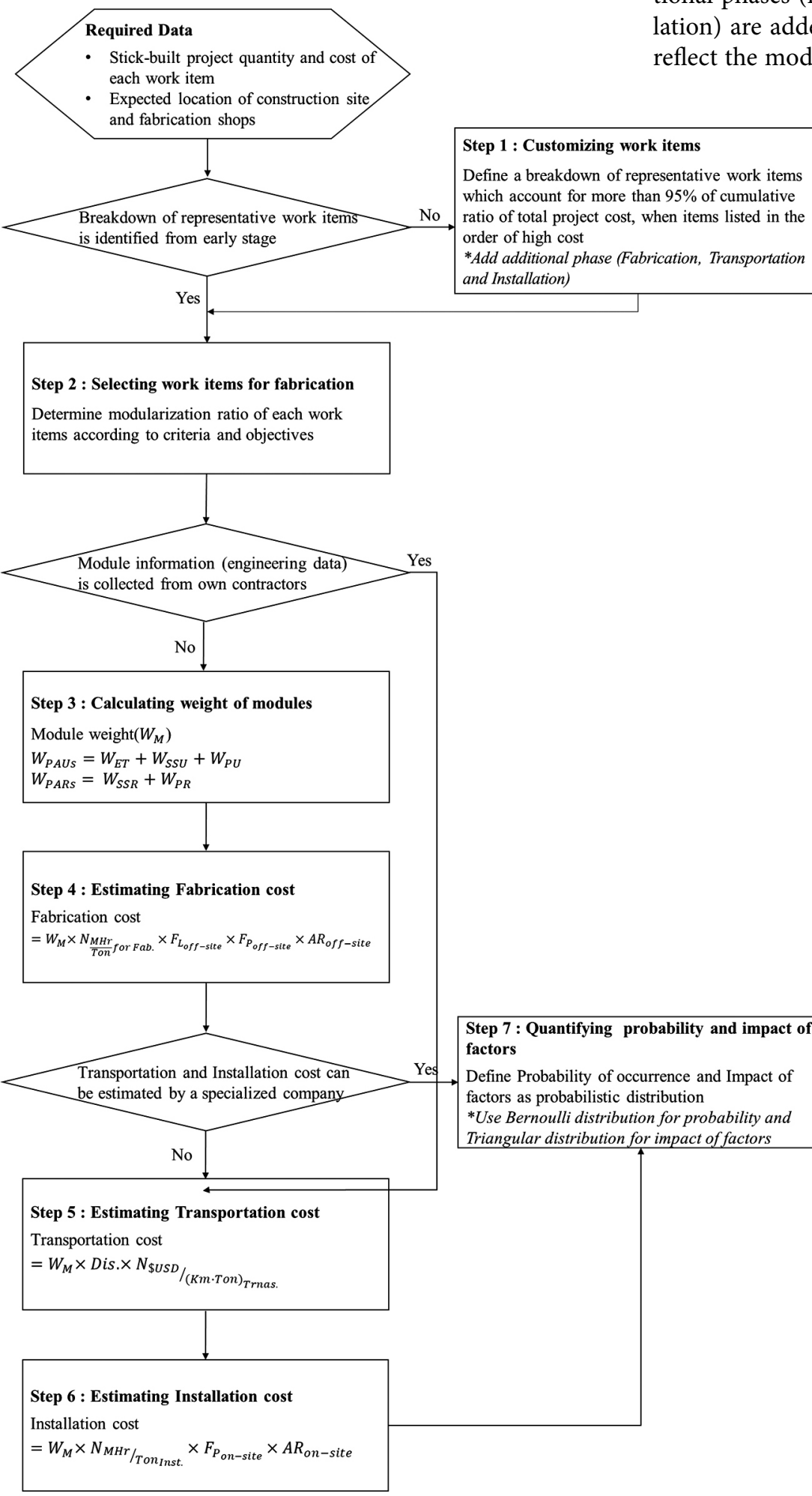

project cost by selecting the representative work items. After the classification of each work item into the appropriate project phase, the user identifies the proportion of each work item's cost to the total project cost. Then, the user lists them in order by their proportion of cost (in descending order, highest first), and finally, defines a cost structure of work items that together combine to cover more than $95 \%$ of the total project cost. Finally, the additional phases (i.e., fabrication, transportation, and installation) are added to the breakdown of the work items to reflect the modular construction process.

Figure 1. The Process of modular cost estimation framework

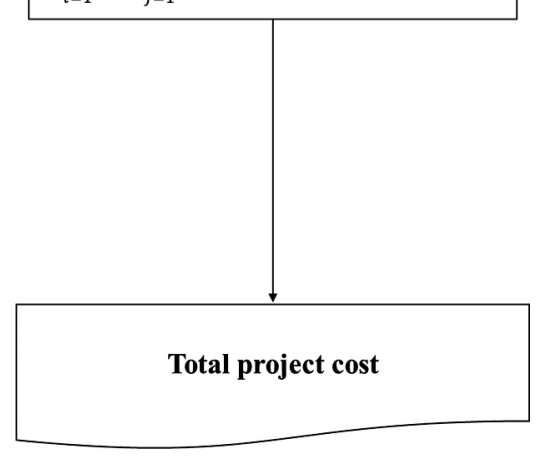




\section{Step 2: Selecting work items for modularization}

Step 2 aims to select work items that are transferred from the construction site to the fabrication shops. Since a module is a completed system that is assembled in the fabrication shops (Haas et al., 2000), it should be assembled with a certain percentage of each work item included. In addition, each project requires a different modularization application area, and thus corresponds to a different transfer ratio for each work item. According to industry practitioners, there are some objectives and criteria for adopting modularization. The objectives include: (1) owner's requirements, (2) environment damage minimization, (3) cost reduction, (4) duration reduction, and (5) improvement in quality. The criteria for applying the modularization area include: (1) the construction process plan, (2) an impossible stick-built construction area, (3) repeatability of work, (4) limitation of transport because of module size, and (5) existence of special equipment. The user selects work items of fabrication parts regarding different criteria and objectives for adopting the modularization.

The user sets the modular application area for the main elements composing an industrial project approximately. Then, based on user experience, the user determines the transfer ratio of each work item, which is defined in Step 1, to calculate the quantities of the work items for each module. Once the quantities are determined, they are converted to modules to be manufactured in the fabrication shops.

\section{Step 3: Calculating weight of modules}

If contractors have module configuration information, they can calculate the weight given to each of the modules easily. However, most contractors lack such experience and cannot attempt to calculate the weight of modules. Thus, the weight of modules is approximately calculated from the quantity of major work items in this step. According to practitioners, the assembled modules are divided into pre-assembled units (PAUs) and pre-assembled racks (PARs):

$$
W_{M}=W_{P A U s}+W_{P A R s},
$$

where $W_{M}$ is the summation of the weights of PAUs and PARs (in tons), $W_{P A U s}$ is the total weight of PAUs (in tons), and $W_{P A R s}$ is the total weight of PARs (in tons).

Even though the elements of the modules comprise many work items, the weights of PAUs and PARs can be calculated from the major work items. First, the majority of the weight of PAUs is comprised of (1) $20 \%$ in equipment work, (2) 50\% in structural steel work, and (3) $30 \%$ in piping work (Compass International Inc., 2016b). Therefore, the weight of structural steel work and piping work can be calculated using that of the equipment work. Thus, this study first assigned the weight of total equipment, and then added the weight of structural steel work and piping work with the ratio mentioned above for PAUs:

$$
W_{P A U S}=W_{E T}+W_{S S U}+W_{P U}
$$

where $W_{E T}$ is the total weight of the equipment trans- ferred into fabrication (in tons), $W_{S S U}$ is the partial weight of the structural steel work for PAUs $\left[=5 / 2 W_{E T}\right]$ (in tons), and $W_{P U}$ is the partial weight of the piping work for PAUs $\left[=3 / 2 W_{E T}\right]$ (in tons).

Second, the majority of the weight of PARs is comprised of (1) structural steel work and (2) piping work (Compass International Inc., 2016b). PARs are calculated with the leftover weight of the structural steel work and piping work after allocating the partial weight of structural steel work (WSSU) and piping work (WPU) for PAUs:

$$
W_{P A R s}=W_{S S R}+W_{P R},
$$

where $W_{S S R}$ is the partial weight of structural steel for PARs [ $\left.=W_{S S T}-W_{S S U}\right]$ (in tons), $W_{S S T}$ is the total weight of structural steel work transferred into fabrication (in tons), $W_{P R}$ is the partial weight of the pipe for PARs [= $W_{P T}-W_{P U}$ (in tons), and $W_{P T}$ is the total weight of piping work transferred into fabrication (in tons).

\section{Step 4: Estimating fabrication cost}

Once the weight of the modules is calculated, the fabrication cost can be estimated by using the construction cost database. Before developing the estimation equation, it is important to reflect the characteristics of the fabrication shops. According to previous studies, the modularization can expect better productivity with all necessary facilities and use cheaper labor than at the construction site (CII, 2002; Mao et al., 2016; Compass International Inc., 2016b). To grasp the entirety of modularization effects, the fabrication cost must reflect this advantage.

For estimating the fabrication cost, this study combined several national factors and values based on practitioners' opinions. The national averages and annual values are listed in the construction cost database. The user selects the values with the corresponding location of the fabrication shops (Step 4). The fabrication cost is derived as:

Fabrication Cost $=$

$$
W_{M} \times N_{M H r / T_{\text {Ton }} .} \times F_{L_{\text {off-site }}} \times F_{P_{\text {off-site }}} \times A R_{\text {off-site }},
$$

where $N_{M H r / T o n_{F a b}}$ is the approximate MHr/Ton using the U.S. Gulf Coast basis for stick-built work (in Mhr/ton); $F_{L_{\text {off-site }}}$ is a country-applicable labor productivity factor applicable to fabrication shops for process facility, offshore work, and modules; $F_{P_{\text {off-site }}}$ is the country productivity factor applicable to fabrication shops compared against a U.S. basis; and $A R_{\text {off-site }}$ is the all-in hourly labor rate for skilled and unskilled construction workers corresponding to fabrication shops (in USD/hr).

The remaining quantity excluded from the fabrication is estimated by interpolation using the stick-built quantity and cost:

$$
\text { Remaining stick-built cost }=C_{W} \times \frac{Q_{F a b}}{Q_{T}},
$$

where $C_{W}$ is the original stick-built cost of each work item, $Q_{T}$ is the total quantity of each work item, and $Q_{F a b}$. is the quantity of each work item transferred into modular fabrication. 


\section{Step 5 and 6: Estimating transportation} and installation costs

Costs for the extra processes for modular construction are high, not only the transportation cost from the fabrication shops to the construction site, but also the installation cost for the modules. Of course, these costs do not apply to the stick-built process (Choi \& Song, 2014; CII, 2002; Jameson, 2007). The transportation and installation for the modules are carried out by specialized companies. However, if the estimates cannot be provided by a professional company, the costs should be approximately estimated by using a simple equation.

This study combined several national factors and values based on practitioners' opinions to calculate the transportation and installation costs, which are similar to those shown in Eqn (4). The transportation cost can be calculated as:

$$
\text { Transportation cost }=W_{M} \times \text { Dis. } \times N_{U S D /\left(\mathrm{km}^{*} \text { ton }\right)},
$$

where Dis. approximates the maritime and land distance between the construction site and the fabrication shops and $N_{U S D /\left(k m^{*} \text { ton }\right)}$ is the shipping cost per ton of the module per kilometer (in USD/ $\mathrm{km}^{\star}$ ton).

The installation cost can be calculated using Eqn (7), where the user selects the national averages and annual values which correspond with the location of the construction site:

$$
\begin{aligned}
& \text { Installation cost }= \\
& W_{M} \times N_{M H r / T o n_{\text {inst. }}} \times F_{P_{\text {on-site }}} \times A R_{\text {on-site }},
\end{aligned}
$$

where $N_{M h r / t o n_{\text {inst. }}}$ is an approximate Mhr/ton using the U.S. Gulf Coast basis for module installation (in Mhr/ ton); $F_{P_{\text {on-site }}}$ indicates the country productivity factor corresponding to the construction site compared against a U.S. basis; and $A R_{\text {on-site }}$ is the all-in hourly labor rate for skilled and unskilled construction workers corresponding to the construction site (in USD/hr).

\section{Step 7: Identifying and quantifying the factors influencing the cost variance}

This step aims to identify the influencing factors on cost, which have caused variation in estimating cost. This study conducted comprehensive literature reviews and expert interview to identify the factors. In the related literature and reports, major consideration and lessons learned from previously completed modular construction projects have been presented. This study categorized them as negative factors due to the application of modularization. On the contrary, the benefits and advantages of modular construction were presented. The author categorized them as positive factors due to the application of modularization. The factors indicated negative and positive effects compared to stick-built projects. Finally, 10 cost factors that affect each work item and phase in industrial modular projects were identified (Table 2). The factors were reviewed by industry practitioners, and they were modified and selected from a cost perspective.

\section{Step 8: Monte-Carlo simulation}

In the last step, the user calculates the total project cost using MCS. There are different probabilities and impacts of each factor on the work items and phases. The quantitative method used in this study has been traditionally estimated by two values, as suggested previously (CII, 2003; Renn, 1998). For example, let the influencing factor $1=\mathrm{F} 1$, the probability of factor $1=\mathrm{P} 1$, and the impact of factor $1=$ I1. F1 affects certain work items (e.g., piping work and structural steel work), P1 equals an occurrence percentage from Bernoulli distribution (e.g., occurrence of $30 \%$ and non-occurrence of 70\%), and I1 equals a percentage from the triangular distribution (e.g., a lower limit of 5\%, a mode of $10 \%$, and an upper limit of $15 \%$ ). In addition, if the influencing factor affects a certain phase, then each work item in the phase is affected.

The objective function is a summation of the noninfluenced and influenced costs, which are multiplied by the probability and impact of factors. Since the costs are presented as a range, the user selects a certain value. The following Eqn (8) shows the objective function:

$$
\text { Total Project Cost }=\sum_{i=1}^{n} C_{i}+\sum_{j=1}^{m} C_{j} \times\left(1+P_{j} \times I_{j}\right),
$$

where $C_{i}$ and $C_{j}$ are the cost items that are not influenced by the factors (expressed in USD) and that are influenced by the factors (also expressed in USD), respectively; $P_{j}$ is the probability of occurrence for the factors (\%); and $I_{j}$ is the impact of the factors (\%).

\subsection{Data collection}

This paper proposes an approximate probability and impact of the factors to help practitioners enter appropriate values (Step 7). These values were obtained by expert survey to reflect their experience from previous projects (Appendix). Seven projects conducted by four Korean contractors in seven countries were selected and the survey collecting the information was distributed. The project costs for each of the seven were between 300 million USD and 6 billion USD. The locations of the projects were in the Middle East, North America, and Asia; 70\% of all respondents had more than 15 years of industrial project experience and $50 \%$ were responsible for project management on their projects. Table 3 and 4 shows the profile of the previously completed projects that we used in this study.

Table 5 provides a list of the 11 probability and impact factors quantified from the survey. The probability values are defined as the number of occurrences in the seven surveyed projects and respondents. For example, let us assume that an influencing factor occurred in 8 out of 10 of the previous projects; then probability of the factor was assumed conservatively to be conservatively $80 \%$. The impact was estimated based on the results of the respondents' experience and expertise. This study used an interval scale in accordance with the factor's degree of affecting the cost estimates, using based on the question number 4 in Appendix. Even if the interval scale cannot express the 
exact impact value that affected the project cost, the respondents can distinguish the approximate range of impact value (Jung \& Han, 2017). In the case of sufficient raw data (from more than five of the projects), the impact values were selected based on fitment into the triangular distribution. On the other hand, in the case of insufficient raw data (from fewer than five of the projects), the average value of the available data was used. However, it was noted that the relationship between the probability and impact values and the influencing factors can be changed and modified by the users for other new projects, which is required for proper analysis.

Table 2. Factors influencing the cost variance in industrial modular projects

\begin{tabular}{|c|c|c|c|}
\hline Category & Factors & Factor description & Source \\
\hline \multirow{5}{*}{ Negative } & Additional use of materials & $\begin{array}{l}\text { Use of stiffeners for modular logistics } \\
\text { transportation }\end{array}$ & $\begin{array}{l}\text { Abdul Nabi \& El-adaway (2020); Choi } \\
\text { and Song (2014); O’Connor et al. } \\
\text { (2013); Shelley (1990) }\end{array}$ \\
\hline & $\begin{array}{l}\text { Need for inspection and } \\
\text { supervision }\end{array}$ & $\begin{array}{l}\text { Large amount of supervision required for } \\
\text { assembling the modules }\end{array}$ & $\begin{array}{l}\text { De La Torre (1994); O’Connor et al. } \\
(2013)\end{array}$ \\
\hline & $\begin{array}{l}\text { Additional fabrication yard } \\
\text { and machine arrangement }\end{array}$ & $\begin{array}{l}\text { Additional machines and space for module } \\
\text { installation }\end{array}$ & $\begin{array}{l}\text { Abdul Nabi \& El-adaway (2020); CII } \\
(2002)\end{array}$ \\
\hline & $\begin{array}{l}\text { Need for additional } \\
\text { coordination }\end{array}$ & $\begin{array}{l}\text { The need for communication and control } \\
\text { between activities }\end{array}$ & $\begin{array}{l}\text { Sharafi et al. (2018); Stubbs and Emes } \\
(1990)\end{array}$ \\
\hline & $\begin{array}{l}\text { Increased design and } \\
\text { engineering costs }\end{array}$ & $\begin{array}{l}\text { Additional home office and engineering cost } \\
\text { due to modular design }\end{array}$ & $\begin{array}{l}\text { Abdul Nabi \& El-adaway (2020); Choi } \\
\text { and Song (2014); CII (2002) }\end{array}$ \\
\hline \multirow{6}{*}{ Positive } & $\begin{array}{l}\text { Reduction in project } \\
\text { management manpower }\end{array}$ & $\begin{array}{l}\text { Lower requirement for supervision and } \\
\text { technical requirement }\end{array}$ & $\begin{array}{l}\text { Gibb and Isack (2003); Hesler (1990); } \\
\text { Stubbs and Emes (1990) }\end{array}$ \\
\hline & $\begin{array}{l}\text { Reduction in construction } \\
\text { machine operations }\end{array}$ & $\begin{array}{l}\text { Shortening operation duration and early } \\
\text { sequencing for construction machines }\end{array}$ & $\begin{array}{l}\text { Jameson (2007); Stubbs and Emes } \\
(1990)\end{array}$ \\
\hline & $\begin{array}{l}\text { Reduction in on-site labor } \\
\text { operations }\end{array}$ & $\begin{array}{l}\text { Reduction in input construction labor and } \\
\text { training of available manpower }\end{array}$ & $\begin{array}{l}\text { Choi and Song (2014); Gibb and Isack } \\
\text { (2003); O'Connor et al. (2013) }\end{array}$ \\
\hline & $\begin{array}{l}\text { Reduction in construction } \\
\text { risk }\end{array}$ & $\begin{array}{l}\text { Reduction in construction expense, such } \\
\text { as insurance and Health, Safety, and } \\
\text { Environment (HSE) costs }\end{array}$ & $\begin{array}{l}\text { Choi and Song (2014); CII (2002); Gibb } \\
\text { and Isack (2003) }\end{array}$ \\
\hline & Increase in field efficiency & $\begin{array}{l}\text { Lower requirement for temporary facilities, } \\
\text { major equipment, camp, and supervision }\end{array}$ & $\begin{array}{l}\text { Gibb and Isack (2003); Jameson (2007); } \\
\text { O'Connor et al. (2013) }\end{array}$ \\
\hline & Reduction in project duration & $\begin{array}{l}\text { Fast construction termination due to } \\
\text { simultaneous work }\end{array}$ & $\begin{array}{l}\text { Choi and Song (2014); Gibb and Isack } \\
\text { (2003); Stubbs and Emes (1990) }\end{array}$ \\
\hline
\end{tabular}

Table 3. Project profile

\begin{tabular}{|c|c|c|c|c|}
\hline No. & Product & Region & Price (in billions of USD) & Duration (in Months) \\
\hline 1 & Petrochemical & Middle East & Price $>5$ & $49<$ Dur. $<60$ \\
\hline 2 & Petrochemical & Middle East & $0.5<$ Price $<0.6$ & $49<$ Dur. $<60$ \\
\hline 3 & Petrochemical & North America & $0.3<$ Price $<0.4$ & $25<$ Dur. $<36$ \\
\hline 4 & Petrochemical & North America & $0.3<$ Price $<0.4$ & $25<$ Dur. $<36$ \\
\hline 5 & Petrochemical & Asia & $0.7<$ Price $<0.8$ & $25<$ Dur. $<36$ \\
\hline 6 & LNG & Middle East & $0.7<$ Price $<0.8$ & $37<$ Dur. $<48$ \\
\hline 7 & LNG & Middle East & Price $>5$ & $61<$ Dur. $<72$ \\
\hline
\end{tabular}

Table 4. Respondent profile

\begin{tabular}{|c|c|c|c|c|}
\hline No. & Position & $\begin{array}{c}\text { Experience } \\
\text { (in number of modular projects) }\end{array}$ & $\begin{array}{c}\text { Project participation experience } \\
\text { (in Years) }\end{array}$ & $\begin{array}{c}\text { Total experience } \\
\text { (in Years) }\end{array}$ \\
\hline 1 & PM & 3 & $1 \sim 2$ & $20 \sim 25$ \\
\hline 2 & PM & 2 & $3 \sim 4$ & $20 \sim 25$ \\
\hline 3 & PM & 2 & $1 \sim 2$ & $20 \sim 25$ \\
\hline 4 & PM & 2 & $3 \sim 4$ & $25 \sim 30$ \\
\hline 5 & PM & 2 & $1 \sim 2$ & $25 \sim 30$ \\
\hline 6 & Eng. & 1 & $1 \sim 2$ & $10 \sim 15$ \\
\hline 7 & Eng. & 1 & $1 \sim 2$ & $20 \sim 25$ \\
\hline 8 & Eng. & 1 & $3 \sim 4$ & $15 \sim 30$ \\
\hline 9 & Eng. & 2 & $3 \sim 4$ & $10 \sim 15$ \\
\hline 10 & Eng. & 2 & $3 \sim 4$ & $10 \sim 15$ \\
\hline
\end{tabular}


Table 5. Probability and impact of the factors influencing differences in cost

\begin{tabular}{|c|c|c|c|c|c|c|}
\hline \multirow[b]{2}{*}{ Category } & \multirow[b]{2}{*}{ Factors } & \multirow[b]{2}{*}{ Influenced phase or work items } & \multirow{2}{*}{$\begin{array}{c}\text { Prob. } \\
(\%)\end{array}$} & \multicolumn{3}{|c|}{ Triangular distribution of cost impact } \\
\hline & & & & $\begin{array}{c}\text { Lower limit } \\
(\%)\end{array}$ & $\begin{array}{c}\text { Mode } \\
(\%)\end{array}$ & $\begin{array}{l}\text { Upper limit } \\
(\%)\end{array}$ \\
\hline \multirow{10}{*}{ Negative } & \multirow[t]{2}{*}{ Additional use of materials } & Structural steel & 80 & 2.0 & 9.4 & 24.1 \\
\hline & & Module transportation & 80 & 2.0 & 7.2 & 10.8 \\
\hline & \multirow[t]{3}{*}{ Need for inspection and supervision } & Project management & 70 & 2.0 & 4.3 & 8.9 \\
\hline & & Fabrication & 60 & 2.0 & 6.0 & 14.0 \\
\hline & & Construction & 50 & 2.0 & 3.4 & 6.3 \\
\hline & \multirow{2}{*}{$\begin{array}{l}\text { Additional fabrication yard and } \\
\text { machine arrangement }\end{array}$} & Project management & 40 & 1.5 & 3.5 & 5.0 \\
\hline & & Modules installation & 70 & 2.0 & 3.3 & 5.8 \\
\hline & Need for additional coordination & Project management & 50 & 2.0 & 3.2 & 5.6 \\
\hline & \multirow{2}{*}{$\begin{array}{l}\text { Increase in design and engineering } \\
\text { man-hour }\end{array}$} & Basic design & 80 & 1.2 & 3.7 & 5.0 \\
\hline & & Detailed design & 80 & 2.0 & 7.2 & 17.7 \\
\hline \multirow{11}{*}{ Positive } & \multirow{3}{*}{$\begin{array}{l}\text { Reduction in project management } \\
\text { manpower }\end{array}$} & Project management & 30 & -8.0 & -6.5 & -3.5 \\
\hline & & Fabrication & 50 & -8.0 & -6.8 & -4.3 \\
\hline & & Construction & 40 & -15.0 & -10.7 & -2.1 \\
\hline & \multirow{2}{*}{$\begin{array}{l}\text { Reduction in construction machine } \\
\text { operations }\end{array}$} & Fabrication & 30 & -15.5 & -6.5 & -2.0 \\
\hline & & Construction & 50 & -12.0 & -10.7 & -8.2 \\
\hline & Reduction in on-site labour operations & Construction & 80 & -18.0 & -10.1 & -2.0 \\
\hline & Reduction in construction risk & Construction & 50 & -12.0 & -9.2 & -3.5 \\
\hline & \multirow[t]{2}{*}{ Increase in field efficiency } & Project management & 20 & -8.0 & -6.5 & -5.0 \\
\hline & & Construction & 40 & -13.5 & -8.0 & -5.0 \\
\hline & \multirow[t]{2}{*}{ Reduction in project duration } & Fabrication & 30 & -17.0 & -11.0 & -.8 .0 \\
\hline & & Construction & 50 & -18.9 & -7.6 & -2.0 \\
\hline
\end{tabular}

\section{Case study}

This section presents the application of the framework developed. To demonstrate the cost estimation practices, a case study was carried out for an ongoing industrial project. As discussed, the cost estimation procedure differs by module information (previous engineering data) and request to a logistics-specialized company. To illustrate the procedure, the selected case covers all distinctive procedures discussed in this study and is expected to help understand the framework. Additionally, the case project is used to verify the framework for the accuracy of estimated cost through a comparison with the detailed engineers' estimate.

\subsection{Overview of the project}

The case project is to build a petrochemical plant in $\mathrm{Ku}$ wait, in which two Korean and one American construction contractors are participating as a joint venture. The initial estimated cost of the project was approximately five billion dollars and the duration was 45 months. The contract covered every character of expense, including profits and incentives, as well as minor penalties for delays. Modularization was discussed between the owner and contractors in an early stage of the project for three reasons. First, there were low oil prices in the international market in 2016 (Mohaddes \& Pesaran, 2017). To avoid a deficit from these low oil prices, getting the project into early opera- tion was the key. Second, since the joint contractors have insufficient connection with any local sub-contractors, the primary contractors ended up making a contract with local sub-contractors at a high price. Third, the project was located in Kuwait, which is known for harsh environments such as high temperature and hurricanes. The location made the supply of labor and equipment difficult for the contractors to handle. In this study, the case project cost was calculated using two modularization scenarios (assuming different locations of the fabrication shop) and one stick-built scenario, and the cost of each scenario was compared.

\subsection{Input of required information}

Table 6 shows the required information for cost estimation. For both modularization scenarios, the construction site was Kuwait. The fabrication shops' locations included the Philippines and the UAE in the first scenario, and South Korea and Japan in the second scenario. The costs for each scenario were adjusted by the location of the selected fabrication shops. For calculating the distance from the fabrication shops to the construction site, the author first obtained the nautical miles from SeaRates, which provides shippers and cargo agent with the transportation routes, and then converted the distance to kilometers. The construction cost data for both scenarios in 2016 was chosen as the basis because the case project started at that point. Each national value can be provided by the 
Table 6. Modularization scenario information for cost estimation

\begin{tabular}{|c|c|c|}
\hline Category & Scenario 1 & Scenario 2 \\
\hline Point of estimation (year) & 2016 & 2016 \\
\hline Construction site location & Kuwait & Kuwait \\
\hline 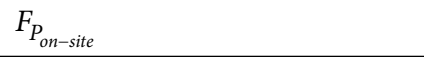 & 2.10 & 2.10 \\
\hline$A R_{\text {on-site }}(\mathrm{USD} / \mathrm{hr})$ & 18.00 & 18.00 \\
\hline $\begin{array}{l}\text { Fabrication shop location } \\
\text { (PAUs) }\end{array}$ & Philippines & South Korea \\
\hline$F_{L_{\text {off-site }}}$ & 0.90 & 0.95 \\
\hline$F_{P_{\text {off-site }}}$ & 2.33 & 1.20 \\
\hline$A R_{o f f-s i t e}(\mathrm{USD} / \mathrm{hr})$ & 11.50 & 34.5 \\
\hline $\begin{array}{l}\text { Fabrication shop location } \\
\text { (PARs) }\end{array}$ & UAE & Japan \\
\hline$F_{L_{\text {off-site }}}$ & 0.96 & 1.04 \\
\hline$F_{P_{\text {off-site }}}$ & 1.45 & 1.20 \\
\hline$A R_{o f f-s i t e}(\mathrm{USD} / \mathrm{Hr})$ & 21.50 & 55.5 \\
\hline $\begin{array}{l}\text { Distance from fabrication shops } \\
\text { to construction site (PAUs) }\end{array}$ & 9,527 & 11,716 \\
\hline $\begin{array}{l}\text { Distance from fabrication shops } \\
\text { to construction site (PARs) }\end{array}$ & 824 & 10,142 \\
\hline$N_{M_{H r / T o n} \text { Fab. }}(\mathrm{Mhr} /$ ton $)$ & 80.00 & 80.00 \\
\hline$N_{\$ U S D / K m \cdot T o n_{\text {Trans. }}}(\mathrm{USD} / \mathrm{km} \cdot \mathrm{ton})$ & 0.15 & 0.15 \\
\hline$N_{M H r / T o n_{\text {Inst. }}}(\mathrm{Mhr} /$ ton $)$ & 6.00 & 6.00 \\
\hline
\end{tabular}

construction cost database (Compass International Inc., 2016a), which presents the minimum through maximum range for the values. These values were manually set to an average value in this study.

\subsection{Cost estimation of each scenario}

The list of work items for the project was sorted in order to select the representative work items (Step 1). The selection process was conducted in the following two stages: According to the identified reverse order (highest first) of that item's portion of the cost, seven phases were selected (management, engineering, procurement, fabrication, construction, transportation, and installation) with a total of 21 detailed work items. The fabrication, transportation, and installation phases were added for adopting modularization; hence, the quantities and costs were not applicable (N/A) to these phases, as shown in Table 7.

It is important to identify the objectives and criteria for adopting modularization in order to select a modular application area in the case project (Step 2). The case project selected the water treatment facilities for the application area, including hydrogen compression, hydrogen production, sulfur recovery, and interconnecting pipe way. Then, the user calculated the approximate quantities of work items. Table 8 describes the transfer ratio of each selected work item (\% MOD) and the estimation proce- dure for scenarios 1 and 2. The table includes the estimation of work items for the corresponding steps illustrated in Figure 1 and the outcomes acquired from the formulas (Steps 2-7). In this study, the constraints of overland transportation, such as road width, tunnels, bridges, and electric lines, were not considered for the estimation of module transportation because that information during the early stage was largely unavailable.

The final step in the framework was the estimation of the total project cost considering the use of MCS and the cost comparison sheet (Step 9). The simulation iteration was set to 1000 trials with an $80 \%$ confidence interval for each factor using @Risk, which can analyze the results in a Microsoft Excel spreadsheet. To calculate the total project cost of scenarios 1 and 2 in the comparison, both the probability and impact of factors from Table 5 were used (Step 8).

Table 9 shows the estimated simulation results along with the stick-built estimate and shows the cost difference between the modular construction (scenarios 1 and 2) and stick-built. Overall, the total project cost for scenario 1 was estimated to be USD 2,716,335,695 and that for scenario 2 was estimated to be USD 2,913,765,768. Based on the simulation results, Scenario 1 had approximately a 5.9\% lower estimate than the stick-built estimate with an increase in management, engineering, and procurement phases and decrease in construction phase. The project management cost was increased due to the comprehensive effect of the factors, although there are also positive factors that affect project management. In addition, the construction phase costs were decreased because its work items were transferred into the fabrication shops and manufactured as modules. On the other hand, Scenario 2 had approximately $1.0 \%$ higher estimate than the stick-built estimate. Scenario 2 tended to estimate similarly to scenario 1 , but the higher estimate in fabrication and transportation may result in increasing total project cost. These outcomes can result from a higher all-in labor rate and farther distance from the fabrication shops to the construction site as compared to scenario 1 .

To verify the accuracy of cost estimation, this study compared scenario 1 from the framework with the basic and detailed engineer's cost estimate, which is defined under the same conditions as that in scenario 1 for modularization. This study used a level of accuracy that corresponded to the level of project definition at that early stage. This difference is acceptable considering an accuracy range set to $-20 \%$ to $+30 \%$ for early cost estimation compared to the detailed design phase (Christensen et al., 2005). The contractor, who was a participant in the joint venture company in the case project, provided the basic and detailed engineer's estimate for the case project. The basic engineer's estimate was USD 2,765,710,156 and the difference from the scenario was $-1.8 \%$. In terms of comparing them in the same phase, this result demonstrated the potential of using this framework in practice. In addition, the detailed engineer's estimate was USD 3,114,395,375 and the difference from the scenario was $-12.8 \%$. 
Table 7. Breakdown of work items for the case project (step 1)

\begin{tabular}{|c|c|c|c|c|c|}
\hline Phase & Classification & Work item & Unit of measure & Quantity & Cost \\
\hline Management & Common & Project management & Hour & $4,680,064$ & $424,158,000$ \\
\hline \multirow{2}{*}{ Engineering } & Common & Basic design & Hour & 800,460 & $113,969,000$ \\
\hline & Common & Detailed design & Hour & $3,644,600$ & $287,986,000$ \\
\hline \multirow{3}{*}{ Procurement } & Common & Equipment & Ton & 23,395 & $538,085,000$ \\
\hline & Common & Structure steel & Ton & 33,103 & $69,516,300$ \\
\hline & Common & Piping & Ton & 27,552 & $137,760,000$ \\
\hline \multirow{2}{*}{ Fabrication } & Modularization & Pre-Assembled Units (PAUs) & Ton & N/A & N/A \\
\hline & Modularization & Pre-Assembled Racks (PARs) & Ton & N/A & N/A \\
\hline \multirow{11}{*}{ Construction } & Common & Site and civil work & Cubic meter & $1,760,631$ & $177,173,100$ \\
\hline & Common & Concrete work & Cubic meter & 393,353 & $320,412,138$ \\
\hline & Common & Building & Square meter & 267,085 & $199,111,981$ \\
\hline & Common & Insulation work & Square meter & 64,274 & $26,655,038$ \\
\hline & Common & Fireproofing work & Square meter & 46,430 & $3,784,788$ \\
\hline & Common & Structural Steel work & Ton & 33,103 & $46,423,163$ \\
\hline & Common & Equipment work & Ton & 23,395 & $49,885,225$ \\
\hline & Common & Piping work & Ton & 27,552 & $307,038,225$ \\
\hline & Common & Control systems work & Each & 10,501 & $14,870,863$ \\
\hline & Common & Paint work & Linear meter & 586,416 & $35,846,850$ \\
\hline & Common & Electrical work & Linear meter & $6,430,444$ & $133,367,650$ \\
\hline Transportation & Modularization & Modules transportation & Kilometer-Ton & N/A & N/A \\
\hline Installation & Modularization & Modules installation & Ton & N/A & N/A \\
\hline
\end{tabular}

Table 8. Cost estimation for the case project (Steps 2-7) in scenarios 1 and 2 (US Dollars)

\begin{tabular}{|c|c|c|c|c|c|c|c|}
\hline Phase & \multicolumn{2}{|c|}{ Work item } & Step & $\begin{array}{c}\% \\
\mathrm{MOD}\end{array}$ & $\begin{array}{c}\text { MOD. } \\
\text { Quantity }\end{array}$ & $\begin{array}{c}\text { Remaining stick-built } \\
\text { Quantity }\end{array}$ & Outcome \\
\hline \multicolumn{8}{|c|}{ Common } \\
\hline \multirow{8}{*}{ Construction } & \multicolumn{2}{|l|}{ Insulation work } & 2,3 & 70 & 44,992 & 19,282 & $7,996,511$ \\
\hline & \multicolumn{2}{|c|}{ Fireproofing work } & 2,3 & 25 & 11,608 & 34,823 & $2,838,591$ \\
\hline & \multicolumn{2}{|c|}{ Structural steel work } & 2,3 & 75 & 24,827 & 8,276 & $11,605,791$ \\
\hline & \multicolumn{2}{|c|}{ Equipment work } & 2,3 & 20 & 4,679 & 18,716 & $39,908,180$ \\
\hline & \multicolumn{2}{|l|}{ Piping work } & 2,3 & 75 & 20,664 & 6,888 & $76,759,556$ \\
\hline & \multicolumn{2}{|c|}{ Control systems work } & 2,3 & 30 & 3,150 & 7,351 & $10,409,604$ \\
\hline & \multicolumn{2}{|c|}{ Paint work } & 2,3 & 60 & 351,850 & 234,566 & $14,338,740$ \\
\hline & \multicolumn{2}{|l|}{ Electrical work } & 2,3 & 10 & 643,044 & $5,787,400$ & $120,030,885$ \\
\hline \multicolumn{8}{|c|}{ Scenario 1} \\
\hline \multirow{2}{*}{ Fabrication } & \multicolumn{2}{|c|}{ Pre-Assembled Units (PAUs) } & $3,4,5$ & $\mathrm{~N} / \mathrm{A}$ & 23,395 & $\mathrm{~N} / \mathrm{A}$ & $45,134,570$ \\
\hline & \multicolumn{2}{|c|}{ Pre-Assembled Racks (PARs) } & $3,4,5$ & N/A & 26,775 & N/A & $64,106,375$ \\
\hline \multirow{2}{*}{ Transportation } & \multirow{2}{*}{$\begin{array}{l}\text { Module } \\
\text { transportation }\end{array}$} & PAUs & $3,4,6$ & N/A & $222,884,165$ & N/A & $45,540,707$ \\
\hline & & PARs & $3,4,6$ & N/A & $22,062,600$ & $\mathrm{~N} / \mathrm{A}$ & $5,799,519$ \\
\hline Installation & \multicolumn{2}{|c|}{ Module installation } & $3,4,7$ & $\mathrm{~N} / \mathrm{A}$ & 50,170 & $\mathrm{~N} / \mathrm{A}$ & $11,378,613$ \\
\hline \multicolumn{8}{|c|}{ Scenario 2} \\
\hline \multirow{2}{*}{ Fabrication } & \multicolumn{2}{|c|}{ Pre-Assembled Units (PAUs) } & $3,4,5$ & N/A & 23,395 & N/A & $73,610,028$ \\
\hline & \multicolumn{2}{|c|}{ Pre-Assembled Racks (PARs) } & $3,4,5$ & N/A & 26,775 & N/A & $148,364,873$ \\
\hline \multirow{2}{*}{ Transportation } & \multirow{2}{*}{$\begin{array}{l}\text { Module } \\
\text { transportation }\end{array}$} & PAUs & $3,4,6$ & N/A & $274,095,820$ & N/A & $54,819,164$ \\
\hline & & PARs & $3,4,6$ & N/A & $271,552,050$ & N/A & $54,310,917$ \\
\hline Installation & \multicolumn{2}{|c|}{ Module installation } & $3,4,7$ & N/A & 50,170 & N/A & $11,378,613$ \\
\hline
\end{tabular}


Table 9. Cost comparison sheet for the case project (Steps 8-9))

\begin{tabular}{|c|c|c|c|c|c|c|}
\hline Phase & Work items & Stick-built (US\$) & Scenario 1 (US\$) & Variance (\%) & Scenario 2 (US\$) & Variance (\%) \\
\hline Management & Project management & $424,158,000$ & $437,213,941$ & 3.1 & $437,838,576$ & 3.2 \\
\hline \multirow{2}{*}{ Engineering } & Basic design & $113,969,000$ & $118,399,140$ & 3.9 & $118,359,524$ & 3.9 \\
\hline & Detailed design & $287,986,000$ & $320,466,961$ & 11.3 & $320,333,640$ & 11.2 \\
\hline \multirow{3}{*}{ Procurement } & Equipment & $538,085,000$ & $538,085,000$ & 0.0 & $538,085,000$ & 0.0 \\
\hline & Structure steel & $69,516,300$ & $79,974,376$ & 15.0 & $79,953,721$ & 15.0 \\
\hline & Piping & $137,760,000$ & $137,760,000$ & 0.0 & $137,760,000$ & 0.0 \\
\hline \multirow{2}{*}{ Fabrication } & PAUs & N/A & $46,259,393$ & $\mathrm{~N} / \mathrm{A}$ & $75,427,998$ & N/A \\
\hline & PARs & $\mathrm{N} / \mathrm{A}$ & $45,920,608$ & $\mathrm{~N} / \mathrm{A}$ & $151,397,521$ & $\mathrm{~N} / \mathrm{A}$ \\
\hline \multirow{11}{*}{ Construction } & Site work and civil & $177,173,100$ & $177,173,100$ & 0.0 & $177,173,100$ & 0.0 \\
\hline & Concrete work & $320,412,138$ & $320,412,138$ & 0.0 & $320,412,138$ & 0.0 \\
\hline & Building & $199,111,981$ & $190,111,981$ & -4.5 & $190,111,981$ & -4.5 \\
\hline & Insulation work & $26,655,038$ & $6,673,205$ & -75.0 & $6,669,958$ & -75.0 \\
\hline & Fireproofing work & $3,784,788$ & $2,368,845$ & -37.4 & $2,352,818$ & -37.8 \\
\hline & Structural Steel work & $46,423,163$ & $9,685,201$ & -79.1 & $9,617,580$ & -79.3 \\
\hline & Equipment work & $49,885,225$ & $33,303,955$ & -33.2 & $33,137,197$ & -33.6 \\
\hline & Piping work & $307,038,225$ & $64,056,962$ & -79.1 & $63,869,317$ & -79.2 \\
\hline & Control system work & $14,870,863$ & $8,686,965$ & -41.6 & $8,629,627$ & -42.0 \\
\hline & Paint work & $35,846,850$ & $11,965,886$ & -66.6 & $11,949,711$ & -66.7 \\
\hline & Electrical work & $133,367,650$ & $100,167,512$ & -24.9 & $100,624,351$ & -24.6 \\
\hline Transportation & Modules transportation & $\mathrm{N} / \mathrm{A}$ & $55,401,359$ & $\mathrm{~N} / \mathrm{A}$ & $117,797,610$ & $\mathrm{~N} / \mathrm{A}$ \\
\hline Installation & Modules installation & N/A & $12,249,167$ & N/A & $12,264,400$ & N/A \\
\hline \multicolumn{2}{|c|}{ Total project cost (\$USD) } & $2,886,043,321$ & $2,716,335,695$ & -5.9 & $2,913,687,149$ & 1.0 \\
\hline
\end{tabular}

According to industry practitioners, uncertainties and risks from application of the modular methods (e.g., complex transportation and installation techniques, the lack of experiences) increased costs and resulted in a significant difference in USD 348,685,219 in engineer estimate. Therefore, it could not be concluded that the result of the estimated value from framework is fully positive, it shows that it could be verified through this case study.

\section{Discussion}

Several researchers have emphasized that modularization can reduce total project cost and thus have generated considerable interest in that approach as an alternative to stick-built (Barbosa et al., 2017; Choi et al., 2019b; CII, 2002). This study identifies the positive and negative items affecting modularization project cost and evaluates probability and impact of items via expert survey and interview. The estimation of stick-built and modularization methods can be compared using the developed framework. Modularization may not always be cost-effective compared to stick-built, and sometimes caused a cost increase in the case study. However, the results cannot be generalized to the point that the factors do not always occur with the same probability and impact; that could be a result of changing project characteristics and users.

The study results show that the cost of scenario 1 is lower and scenario 2 is higher than the stick-built estimate. Therefore, total project cost can vary depending on the conditions of the fabrication shops and the dependent logistics. In scenario 1 , the total project cost is reduced due to the low all-in rate in fabrication shops and short transportation distance for one of them. In scenario 2, though project cost is higher than stick-built, the project can achieve the performance improvement such as short duration and high quality of modules due to high productivity and highly skilled workers. These results support that considering the performance trade-offs such as cost, schedule, and quality is necessary for a successful project when the practitioners are attempting to select the fabrication shops.

To evaluate the influence of the factors on total project cost, a sensitivity analysis was completed by examining the result of the estimation from the framework. The sensitivity analysis allows this study to be more interpretable and provides several scenarios (El Asmar et al., 2009). The analysis results are shown in Figures $2 \mathrm{a}$ and $2 \mathrm{~b}$. The Tornado diagrams show the cost variation ratio of each project phase, which indicates the influence of factors compared to stick-built. The cost of the construction phases of both scenarios 1 and 2 is subject to the largest variation. Thus, contractors should attempt to manage closely the work items of this phase since it has the highest percentage of costs with the largest variation. The fabrication phase ranks second on the list in scenario 2 because the cost of fabrication in scenario 2 is larger than that in scenario 1 . This implies that practitioners should be concerned for the fabrication phase when increasing the modularization 
a)

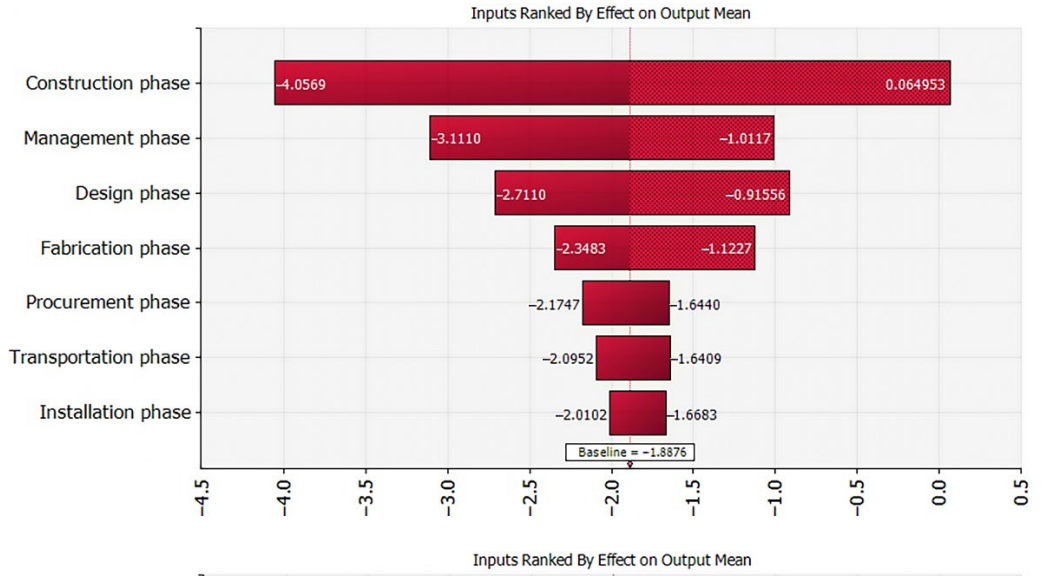

b)

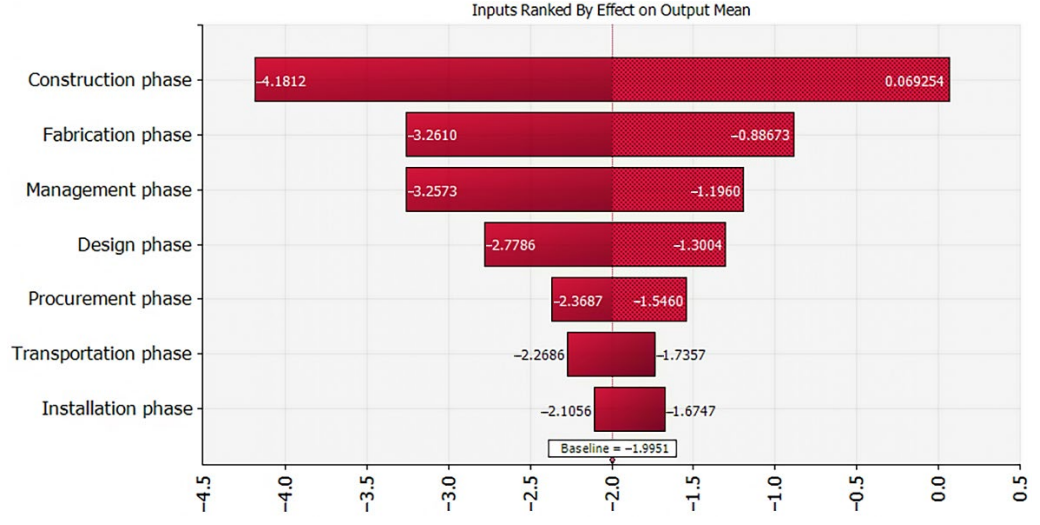

Figure 2. Tornado diagram of the cost variation ratio of scenario 1 (a) and 2 (b)

ratio and its cost on their projects. On the contrary, the procurement, transportation, and installation phases do not show a significant cost variation ratio and the ranking remains unchanged. Therefore, these three phases are low priorities for contractors because they are contracted with a specialized company. When contractors make plans for the management scope, the sensitivity analysis results can assist in controlling the project budget.

\section{Conclusions}

This paper develops a framework for estimating industrial modular project cost, which allows for appropriate comparisons between stick-built and modularization approaches. The framework supported inexperienced contractors in estimating total project cost, even though they lacked previous experience and design data, by adjusting from the stick-built cost. This research also conducted a case study to demonstrate the applicability of the framework. The framework was verified through comparison with basic engineer's estimates with a difference of $-1.8 \%$. Even against detailed engineer's estimates, there was a difference of $-12.8 \%$, which was within the expected level of accuracy for this early stage of the project. However, the framework described in this study presents different estimates depending on user input values (Table 5) and there are limitations to generalization from the study: more real data is needed for modeling.

The major contributions of this study can be stated as follows. First, the study attempted to quantify the factors influencing the differences in cost between modularization and stick-built methods based on practitioners' interviews for the petrochemical project. The probability and impact of each factor were presented to reflect their positive and negative impact. Second, this study compared total project cost and cost changes moving to modularization using the framework developed. The cost estimation framework can support decision making regarding the construction method selection despite a lack of information. It is still difficult to be generalized, but the framework is believed to be the first attempt to use mathematical calculations to incorporate the cost differences in modular construction based on the different selected fabrication shops. Therefore, this study practically contributes to the body of knowledge of conceptual cost estimation for industrial modular projects.

Despite these contributions, this study has several limitations. First, the developed framework was dependent on input by industry practitioners' judgment. Thus, the framework results cannot be completely generalized due to inherent difficulties, such as individual bias. Second, the number of sample projects used to quantify the probability and impact of the influencing factors is small. In addition, these values do not capture the location characteristics of the construction site and fabrication shops. Future studies will concentrate on complementing the requirements of more cases for a generalized framework with large amounts of data. Continuous improvement of the framework is required through the evaluation of various industrial project types. Finally, this study did not 
consider how to control the estimated cost, nor how to maximize the modularization. To overcome these limitations, the author's future research will focus on developing a robust cost estimation model applicable to various types of industrial modular projects. It also would be meaningful to analyze the optimal modularization ratio in the specific case where the modularized work items are not properly addressed. Follow-up studies can overcome these limitations and contribute more information for both researchers and practitioners.

\section{Funding}

This work was supported by the 2017 Yeungnam University Research Grant.

\section{Author contributions}

Y.C, C.Y.P and S.H.H conceived and designed the Framework. Y.C collected data, developed the framework, interviewed experts, and wrote the manuscript. C.L and C.Y.P analyzed results and validations and revised the manuscript. S.Y and S.H.H developed the overall idea and revised the manuscript. All authors have read and agreed to the published final manuscript.

\section{Disclosure statement}

The authors declare that no conflict of interest exists.

\section{References}

Abdul Nabi, M., \& El-adaway, I. H. (2020). Modular construction: Determining decision-making factors and future research needs. Journal of Management and Engineering, 36(6), 04020085 .

https://doi.org/10.1061/(ASCE)ME.1943-5479.0000859

Abdul Nabi, M., \& El-adaway, I. H. (2021). Understanding the key risks affecting cost and schedule performance of modular construction projects. Journal of Management and Engineering, 37(4), 04021023.

https://doi.org/10.1061/(ASCE)ME.1943-5479.0000917

Back, W. E., Boles, W. W., \& Fry, G. T. (2000). Defining triangular probability distributions from historical cost data. Journal of Construction Engineering and Management, 126(1), 29-37. https://doi.org/10.1061/(ASCE)0733-9364(2000)126:1(29)

Barbosa, F., Woetzel, J., Mischke, J., Ribeirinho, M. J., Sridhar, M., Parsons, M., Bertram, N., \& Brown, S. (2017). Reinventing construction: A route to higher productivity. McKinsey Global Institute.

Bell, L. C., \& Kaminsky, A. (1987). Data base for preliminary cost estimating. Journal of Transportation Engineering, 113(4), 341-347.

https://doi.org/10.1061/(ASCE)0733-947X(1987)113:4(341)

Bertram, N., Fuchs, S., Mischke, J., Palter, R., Strube, G., \& Woetzel, J. (2019). Modular construction: From projects to products. McKinsey \& Company.

Cheung, F. K., Rihan, J., Tah, J., Duce, D., \& Kurul, E. (2012). Early stage multi-level cost estimation for schematic BIM models. Automation in Construction, 27, 67-77.

https://doi.org/10.1016/j.autcon.2012.05.008
Choi, J. O. (2014). Links between modularization critical success factors and project performance [Dissertation]. The University of Texas at Austin. https://doi.org/10.1061/9780784413517.167

Choi, J., \& Song, H. (2014). Evaluation of the modular method for industrial plant construction projects. International Journal of Construction Management, 14(3), 171-180.

https://doi.org/10.1080/15623599.2014.922728

Choi, S., Kim, D. Y., Han, S. H., \& Kwak, Y. H. (2014). Conceptual cost-prediction model for public road planning via rough set theory and case-based reasoning. Journal of Construction Engineering and Management, 140(1), 04013026. https://doi.org/10.1061/(ASCE)CO.1943-7862.0000743

Choi, J. O., O’Connor, J. T., Kwak, Y. H., \& Shrestha, B. K. (2019a). Modularization business case analysis model for industrial projects. Journal of Management in Engineering, 35(3), 04019004.

https://doi.org/10.1061/(ASCE)ME.1943-5479.0000683

Choi, J. O., Chen, X. B., \& Kim, T. W. (2019b). Opportunities and challenges of modular methods in dense urban environment. International Journal of Construction Management, 19(2), 93-105. https://doi.org/10.1080/15623599.2017.1382093

Chou, J.-S., Peng, M., Persad, K. R., \& O’Connor, J. T. (2006). Quantity-based approach to preliminary cost estimates for highway projects. Transportation Research Record: Journal of the Transportation Research Board, 1946(1), 22-30. https://doi.org/10.1177/0361198106194600103

Chou, J.-S., Yang, I.-T., \& Chong, W. K. (2009). Probabilistic simulation for developing likelihood distribution of engineering project cost. Automation in Construction, 18(5), 570-577. https://doi.org/10.1016/j.autcon.2008.12.001

Chowdhury, M. M. (2016). Simulation of value stream mapping and discrete optimization of energy consumption in modular construction [MSc thesis]. Illinois State University. http://doi.org/10.30707/ETD2016.Chowdhury.M

Christensen, P., Dysert, L. R., Bates, J., Burton, D., Creese, R., \& Hollmann, J. (2005). Cost estimate classification system-as applied in engineering, procurement, and construction for the process industries. AACE International.

Construction Industry Institute. (2002). Prefabrication, preassembly, modularization and offsite fabrication in industrial construction - A framework for decision making.

Construction Industry Institute. (2003). IPRA: International project risk assessment.

Compass International Inc. (2016a). Global construction costs yearbook (16th Annual ed.).

Compass International Inc. (2016b). Pipelines, mining \& offshore cost data yearbook (15th Annual ed.).

De La Torre, M. L. (1994). A review and analysis of modular construction practices [MSc thesis]. Lehigh University.

Dursun, O., \& Stoy, C. (2016). Conceptual estimation of construction costs using the multistep ahead approach. Journal of Construction Engineering and Management, 142(9), 04016038. https://doi.org/10.1061/(ASCE)CO.1943-7862.0001150

El Asmar, M., Hanna, A. S., \& Chang, C.-K. (2009). Monte Carlo simulation approach to support alliance team selection. Journal of Construction Engineering and Management, 135(10), 10871095. https://doi.org/10.1061/(ASCE)CO.1943-7862.0000074

Fazeli, A., Dashti, M. S., Jalaei, F., \& Khanzadi, M. (2020). An integrated BIM-based approach for cost estimation in construction projects. Engineering, Construction and Architectural Management, 28(9), 2828-2854. https://doi.org/10.1108/ECAM-01-2020-0027

Gibb, A., \& Isack, F. (2003). Re-engineering through pre-assembly: client expectations and drivers. Building Research \& Information, 31(2), 146-160. https://doi.org/10.1080/09613210302000 
Haas, C. T., O’Connor, J. T., Tucker, R., Eickmann, J., \& Fagerlund, W. (2000). Prefabrication and preassembly trends and effects on the construction workforce (Issue 14 of Report). University of Texas at Austin, Center for Construction Industry Studies, USA.

Hashemi, S. T., Ebadati E, O. M., \& Kaur, H. (2019). A hybrid conceptual cost estimating model using ANN and GA for power plant projects. Neural Computing and Applications, 31(7), 2143-2154. https://doi.org/10.1007/s00521-017-3175-5

Hesler, W. E. (1990). Modular design-where it fits. Chemical Engineering Progress, 86(10), 76-80.

Hsu, P.-Y., Angeloudis, P., \& Aurisicchio, M. (2018). Optimal logistics planning for modular construction using two-stage stochastic programming. Automation in Construction, 94, 47-61. https://doi.org/10.1016/j.autcon.2018.05.029

Jameson, P. (2007). Is modularization right for your project? $H y$ drocarbon Processing, 86(12), 47-47.

Jung, W., \& Han, S. H. (2017). Which risk management is most crucial for controlling project cost? Journal of Management in Engineering, 33(5), 04017029.

https://doi.org/10.1061/(ASCE)ME.1943-5479.0000547

Kang, H.-W., \& Kim, Y.-S. (2018). A model for risk cost and bidding price prediction based on risk information in plant construction projects. KSCE Journal of Civil Engineering, 22(11), 4215-4229. https://doi.org/10.1007/s12205-018-0587-4

Kim, S.-B., \& Cho, J.-H. (2013). Development of the approximate cost estimating model for PSC box girder bridge based on the breakdown of standard work. Journal of the Korean Society of Civil Engineers, 33(2), 791-800.

https://doi.org/10.12652/Ksce.2013.33.2.791

Kim, G.-H., An, S.-H., \& Kang, K.-I. (2004). Comparison of construction cost estimating models based on regression analysis, neural networks, and case-based reasoning. Building and Environment, 39(10), 1235-1242.

https://doi.org/10.1016/j.buildenv.2004.02.013

Kim, K. J., Kim, K., \& Kang, C. S. (2009). Approximate cost estimating model for PSC Beam bridge based on quantity of standard work. KSCE Journal of Civil Engineering, 13(6), 377-388. https://doi.org/10.1007/s12205-009-0377-0

Kinney, C. L., \& Soubiran, N. (2004). Interactive roadmap to conceptual cost estimating. Cost Engineering, 46(9), 31-40.

Koo, C., Hong, T., \& Hyun, C. (2011). The development of a construction cost prediction model with improved prediction capacity using the advanced CBR approach. Expert Systems with Applications, 38(7), 8597-8606.

https://doi.org/10.1016/j.eswa.2011.01.063

Kwak, Y. H., \& Watson, R. J. (2005). Conceptual estimating tool for technology-driven projects: exploring parametric estimating technique. Technovation, 25(12), 1430-1436. https://doi.org/10.1016/j.technovation.2004.10.007

Mao, C., Xie, F., Hou, L., Wu, P., Wang, J., \& Wang, X. (2016). Cost analysis for sustainable off-site construction based on a multiple-case study in China. Habitat International, 57, 215222. https://doi.org/10.1016/j.habitatint.2016.08.002

Mohaddes, K., \& Pesaran, M. H. (2017). Oil prices and the global economy: Is it different this time around? Energy Economics, 65, 315-325. https://doi.org/10.1016/j.eneco.2017.05.011

Naqvi, D., Wey, E., Patel, J., \& Siegert, G. (2014). Modularization in the petrochemical industry. In Structures Congress 2014, Boston, Massachusetts, United States. https://doi.org/10.1061/9780784413357.153

O'Connor, J., O’Brien, W., \& Choi, J. (2013). Industrial modularization: How to optimize; How to maximize. University of Texas, Construction Industry Institute, Austin, TX.
O’Connor, J. T., O’Brien, W. J., \& Choi, J. O. (2014). Critical success factors and enablers for optimum and maximum industrial modularization. Journal of Construction Engineering and Management, 140(6), 04014012.

https://doi.org/10.1061/(ASCE)CO.1943-7862.0000842

O’Connor, J. T., O'Brien, W. J., \& Choi, J. O. (2015). Standardization strategy for modular industrial plants. Journal of Construction Engineering and Management, 141(9), 04015026. https://doi.org/10.1061/(ASCE)CO.1943-7862.0001001

Oberlender, G. D., \& Trost, S. M. (2001). Predicting accuracy of early cost estimates based on estimate quality. Journal of Construction Engineering and Management, 127(3), 173-182. https://doi.org/10.1061/(ASCE)0733-9364(2001)127:3(173)

Pan, W., Dainty, A. R., \& Gibb, A. G. (2012). Establishing and weighting decision criteria for building system selection in housing construction. Journal of Construction Engineering and Management, 138(11), 1239-1250. https://doi.org/10.1061/(ASCE)CO.1943-7862.0000543

Petroutsatou, K., Georgopoulos, E., Lambropoulos, S., \& Pantouvakis, J. P. (2012). Early cost estimating of road tunnel construction using neural networks. Journal of Construction Engineering and Management, 138(6), 679-687.

https://doi.org/10.1061/(ASCE)CO.1943-7862.0000479

Renn, O. (1998). The role of risk perception for risk management. Reliability Engineering \& System Safety, 59(1), 49-62. https://doi.org/10.1016/S0951-8320(97)00119-1

Sharafi, P., Rashidi, M., Samali, B., Ronagh, H., \& Mortazavi, M. (2018). Identification of factors and decision analysis of the level of modularization in building construction. Journal of Architecture Engineering, 24(2), 04018010.

https://doi.org/10.1061/(ASCE)AE.1943-5568.0000313

Shelley, S. (1990). Making inroads with modular construction. Chemical Engineering, 97(8), 30-35.

Smith, S., Braham, A., Hernandez, S., \& Kent, J. (2018). Development of a cost estimation framework for potential transload facilities. Transportation Research Record: Journal of the Transportation Research Board, 2672(9), 24-34. https://doi.org/10.1177/0361198118774690

Sonmez, R., Ergin, A., \& Birgonul, M. T. (2007). Quantitative methodology for determination of cost contingency in international projects. Journal of Management in Engineering, 23(1), 35-39. https://doi.org/10.1061/(ASCE)0742-597X(2007)23:1(35)

Soutos, M., \& Lowe, D. J. (2005). ProCost - Towards a powerful early stage cost estimating tool. In International Conference on Computing in Civil Engineering 2005, Cancun, Mexico. https://doi.org/10.1061/40794(179)142

Staub-French, S., Fischer, M., Kunz, J., \& Paulson, B. (2003). A generic feature-driven activity-based cost estimation process. Advanced Engineering Informatics, 17(1), 23-39. https://doi.org/10.1016/S1474-0346(03)00017-X

Stubbs, D. L., \& Emes, P. D. (1990). Modularization: Prefabricating a process plant. Mechanical Engineering - CIME, 112(11), 63-66.

Taghaddos, H., Hermann, U., AbouRizk, S., \& Mohamed, Y. (2010). Simulation-based scheduling of modular construction using multi-agent resource allocation. In Proceedings of the 2010 Second International Conference on Advances in System Simulation. IEEE Computer Society. https://doi.org/10.1109/SIMUL.2010.36

Touran, A. (1993). Probabilistic cost estimating with subjective correlations. Journal of Construction Engineering and Management, 119(1), 58-71.

https://doi.org/10.1061/(ASCE)0733-9364(1993)119:1(58) 
Touran, A., \& Wiser, E. P. (1992). Monte Carlo technique with correlated random variables. Journal of Construction Engineering and Management, 118(2), 258-272.

https://doi.org/10.1061/(ASCE)0733-9364(1992)118:2(258)

Uspensky, J. V. (1937). Introduction to mathematical probability (1st ed.). McGraw-Hill.

Wuni, I. Y., Shen, G. Q. P., \& Mahmud, A. T. (2019). Critical risk factors in the application of modular integrated construction: A systematic review. International Journal of Construction Management. https://doi.org/10.1080/15623599.2019.1613212

Wuni, I. Y., Shen, G. Q., \& Hwang, B.-G. (2020). Risks of modular integrated construction: A review and future research directions. Frontiers of Engineering Management, 7(1), 63-80. https://doi.org/10.1007/s42524-019-0059-7
Yu, W. D. (2006). PIREM: a new model for conceptual cost estimation. Construction Management and Economics, 24(3), 259-270. https://doi.org/10.1080/01446190500183735

Zhu, B., Yu, L.-A., \& Geng, Z.-Q. (2016). Cost estimation method based on parallel Monte Carlo simulation and market investigation for engineering construction project. Cluster Computing, 19(3), 1293-1308.

https://doi.org/10.1007/s10586-016-0585-6

\section{APPENDIX}

Survey for Performance assessment of industrial modular projects

\section{Project Information}

Project title; Project (Product) type; Host country; Contractor name; Contract price; Contract period; Location of the construction site (country and city); Location of fabrication shops (country and city)

2. Respondent Information

Respondent name; Affiliation; Assigned task at the project; Work experience in the total construction industry; Work experience in the industrial construction industry

3. Criteria and objective of adopting modularization method

\begin{tabular}{|c|c|c|c|c|c|}
\hline Question & \multicolumn{5}{|c|}{ Evaluation } \\
\hline $\begin{array}{l}\text { What were the objectives for } \\
\text { adopting modularization for your } \\
\text { project? }\end{array}$ & $\begin{array}{l}\text { Owner's } \\
\text { requirement }\end{array}$ & $\begin{array}{l}\text { Environment } \\
\text { damage } \\
\text { minimization }\end{array}$ & Cost reduction & $\begin{array}{l}\text { Duration } \\
\text { Reduction }\end{array}$ & $\begin{array}{l}\text { Improvement } \\
\text { in quality }\end{array}$ \\
\hline \multirow[t]{2}{*}{$\begin{array}{l}\text { What were the criteria for adopting } \\
\text { the modularization for your project? }\end{array}$} & $\begin{array}{l}\text { Construction } \\
\text { process plan }\end{array}$ & $\begin{array}{l}\text { Impossible } \\
\text { stick-built } \\
\text { construction } \\
\text { parts }\end{array}$ & $\begin{array}{l}\text { Repeatability of } \\
\text { work }\end{array}$ & $\begin{array}{c}\text { Pursuit } \\
\text { of better } \\
\text { construction } \\
\text { process }\end{array}$ & $\begin{array}{l}\text { Existence } \\
\text { of special } \\
\text { equipment }\end{array}$ \\
\hline & & & & & \\
\hline
\end{tabular}

4. Quantifying the impact of influence factors on cost in the project

\begin{tabular}{|c|c|c|c|c|c|c|c|c|c|c|}
\hline$\#$ & Question & \multicolumn{9}{|c|}{ Evaluation } \\
\hline \multirow[b]{2}{*}{ N-1 } & What was the influenced work items? & \multicolumn{4}{|c|}{ The influenced work item } & \multicolumn{3}{|c|}{(} & \multicolumn{2}{|c|}{ ) } \\
\hline & $\begin{array}{l}\text { How much was the checked negative } \\
\text { factor in the work item compared to }\end{array}$ & factor & $\mathrm{N} / \mathrm{A}$ & $\begin{array}{c}1 \% \\
- \\
3 \%\end{array}$ & $\begin{array}{c}4 \% \\
- \\
6 \%\end{array}$ & $\begin{array}{c}7 \% \\
- \\
9 \%\end{array}$ & $\begin{array}{c}10 \% \\
- \\
13 \%\end{array}$ & $\begin{array}{c}14 \% \\
- \\
16 \%\end{array}$ & $\begin{array}{c}17 \% \\
- \\
19 \%\end{array}$ & $\begin{array}{c}\text { More } \\
\text { than } \\
20 \%\end{array}$ \\
\hline \multirow{3}{*}{ P-1 } & What was the influenced work items? & \multicolumn{4}{|c|}{ The influenced work item } & \multicolumn{3}{|c|}{ ( } & \multicolumn{2}{|c|}{ ) } \\
\hline & $\begin{array}{l}\text { How much was the checked positive } \\
\text { factor in the work item compared to } \\
\text { stick-built? }\end{array}$ & $\begin{array}{l}\text { factor } \\
\text { impact }\end{array}$ & $\mathrm{N} / \mathrm{A}$ & $\begin{array}{c}1 \% \\
- \\
3 \%\end{array}$ & $\begin{array}{c}4 \% \\
- \\
6 \%\end{array}$ & $\begin{array}{c}7 \% \\
- \\
9 \%\end{array}$ & $\begin{array}{c}10 \% \\
- \\
13 \%\end{array}$ & $\begin{array}{c}14 \% \\
- \\
16 \%\end{array}$ & $\begin{array}{c}17 \% \\
- \\
19 \%\end{array}$ & $\begin{array}{c}\text { More } \\
\text { than } \\
20 \%\end{array}$ \\
\hline & & & & & & & & & & \\
\hline
\end{tabular}

